\title{
EXPERIMENTAL STUDY OF EXPANSIVE SOIL IN NEW URBAN AREAS SURROUNDING CAIRO
}

\author{
E. A. El-Kasaby ${ }^{1}$, A. A. Easa ${ }^{2}$, M. F. Abd-Elmagied ${ }^{3}$, Mohammed G. El-Abd ${ }^{4} *$ \\ ${ }^{1}$ Prof. of soil mechanics and foundations in Civil Engineering Department, Benha Faculty \\ of Engineering, Benha University, Cairo, Egypt. \\ ${ }^{2}$ Associate Professor in Civil Engineering Department, Benha Faculty of Engineering, \\ Benha University, Cairo, Egypt. \\ ${ }^{3}$ Lecturer in Civil Engineering Department, Benha Faculty of Engineering, Benha \\ University, Cairo, Egypt. \\ ${ }^{4}$ Demonstrator in Civil Engineering Department, Benha Faculty of Engineering, Benha \\ University, Cairo, Egypt.
}

\begin{abstract}
Swelling soils in Egypt are found in several areas such as new Cairo, Madinat-Nasr, Alshrouk city, Assuit, New vally, Aswan and Edfu ... etc. This paper discusses the physico-chemical properties and engineering behavior of expansive clays founded in Egyptian desert surrounding Cairo city. Five expansive soil samples were collected at the foundation levels of five different sites in new-built cities surrounding Cairo. Laboratory tests were performed on these soil samples to investigate physical properties of the various samples. Also, soil particle structure and clay mineralogy were investigated using Scanning Electron Microscope and X-Ray Diffraction. The obtained results show that clay mineral, its percentage, chemical composition and consistency limits affecting the swelling behavior. Also, the effect of replacement layer thickness on swelling reduction ratio is studied. The results proved that the efficiency of replacement layers in reducing the swell of expansive soil. Then, Data fit software is used to correlate the experimental results

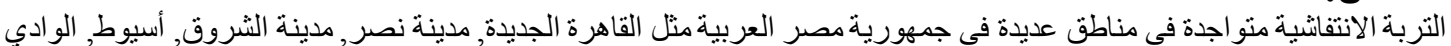

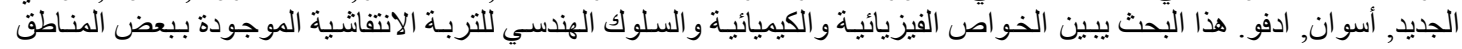

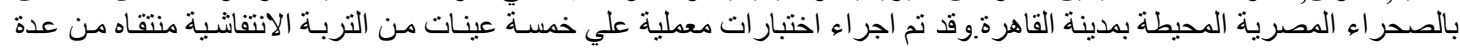

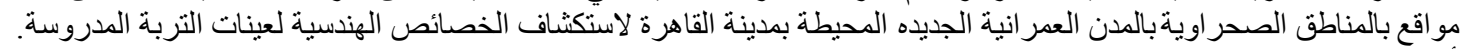

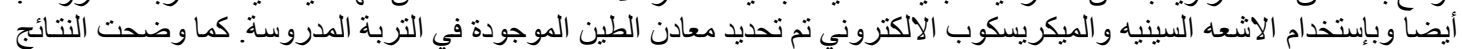

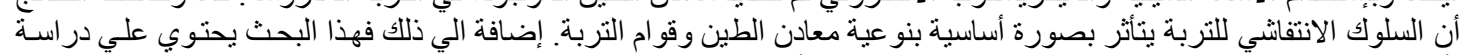

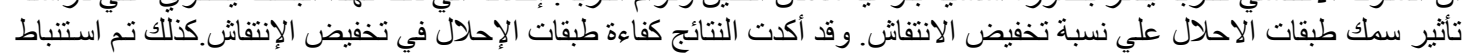

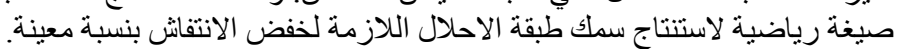

Keywords: New-Built Cities; Soil Properties; Expansive Soil; Swelling; Clay Mineralogy; Replacement Layers 


\section{Introduction}

Expansive soil is plastic soil, which contains mainly clay minerals and is very sensitive to drying or wetting conditions, which exhibit a variety of engineering properties and behavior. Swelling of expansive soil often causes partial and full damages to various civil engineering structures, especially to lightly loaded structures such as houses, pavements, and canals. Swelling of soil causes many geotechnical problems for foundations, and pavement cracks beside canals, hydraulic structures, underground and/or rested on soil tanks [1].

Clay's ability to expansion due to increases in water content, which may be the result of ground water exert an upward pressure on foundation. Expansion of clays and the associated swelling pressure results considerable damages, if the swelling pressure of the soil exceeds the foundation load, uplift causes walls, beams and columns to crack [2].

Many treatment procedures are available for expansive soils [1] and [3]. Excavation of expansive soils and replacement with non-expansive or treated soils used to reduce soil heave under a foundation or subgrade. In this method, the expansive soil excavated to an appropriate depth to minimize heave to an appropriate amount, and then appropriately treated and compacted fill placed to bring the soil up to grade. Factors that considered are the required depth of removal, and the amount, location, and cost of the fill [4] and [5].

Because of the urbanization and land development in Egypt started more than three decades ago in the new urban towns around Cairo, where construction activities extended from the narrow district in the Nile Valley and Delta toward the vast desert fringes. These expansive beds produced many engineering problems for the founded structures. Some of these problems were studied by [6], [7] and [8].

The main aim of this research is to monitor the effect of mineralogical and physico-chemical properties of the tested soils on swelling behavior. Besides, studied effect of increase replacement thickness on swell behavior and correlate swelling reduction ratio with replacement thickness layer.

\section{Experimental Program}

Five clay samples were collected at the foundation levels of five new-built cities surrounding Cairo as listed in table 1 and Fig. 1. The experimental program was carried out in the soil mechanics and foundation laboratory of Benha faculty of engineering, Benha University. Physical properties of the studied soil samples were determined according to the manner testing specifications of [9] and [10]. According to ECP 202-2001, the different pressure method was conducted to determine swelling pressure for the studied soils.

The mineral compositions of five clay samples were examined using X-Ray Diffraction (XRD) and Scanning Electron Microscope (SEM) as [11]. These techniques are available at Housing \& Building National Research Center, Central Laboratories Sector of Egyptian Mineral Resources Authority at Giza, Egypt.

A simple model was performed to identify the effect of replacement layer thickness on the value of free swell. The experimental program was designed to determine the swelling behavior for the studied soil S1 with variable thickness as indicated in Fig. 2.

Table 1. The studied soil locations

\begin{tabular}{|c|c|}
\hline Sample No. & Location \\
\hline S-1 & El Maadi El Gedida \\
\hline S-2 & El Maadi El Gedida \\
\hline S-3 & New Cairo \\
\hline S-4 & Alshrouk city \\
\hline S-5 & Dahshur \\
\hline
\end{tabular}

\section{Results and Analysis}

\subsection{Physical Properties}

Table 2 shows index properties as natural water content, natural unit weight, specific gravity and Atterberg limits of the studied soil. According to unified soil classification system (USCS), and based on these results, it is noticed that:

- The values of natural moisture content $\left(\mathrm{w}_{\mathrm{n}}\right)$ are ranged between $9.15 \%$ and $12.55 \%$ with average value $11.27 \%$. In other side, the values of natural unit weight $\left(\gamma_{\text {nat. }}\right)$ are ranged between 1.72 $\mathrm{gm} / \mathrm{cm}^{3}$ and $1.77 \mathrm{gm} / \mathrm{cm}^{3}$ with average value 1.74 $\mathrm{gm} / \mathrm{cm}^{3}$.

- Specific gravity $\left(\mathrm{G}_{\mathrm{s}}\right)$ values are approximately closed. The highest value of $\mathrm{G}_{\mathrm{s}}$ is 2.71 , the lowest is 2.62 with average value 2.67.

- The values of liquid limit (LL) are ranged between $48.66 \%$ and $93.96 \%$ with average value $76.27 \%$. Additionally, the values of plastic limit (PL) are ranged between $28 \%$ and $41.25 \%$ with average value $36.49 \%$. Accordingly, the soil samples S-1 and S-2 are classified $\mathrm{MH}$. Where $\mathrm{MH}$ represents silt of high plasticity. On the other hand sample S-5 are classified ML (silt of low plasticity). Moreover, the soil samples S-3 and S4 are classified as $\mathrm{CH}$ (clay of high plasticity).

- The values of shrinkage Limit (SL) are ranged between $12.4 \%$ and $15.06 \%$ with average value $13.64 \%$. 


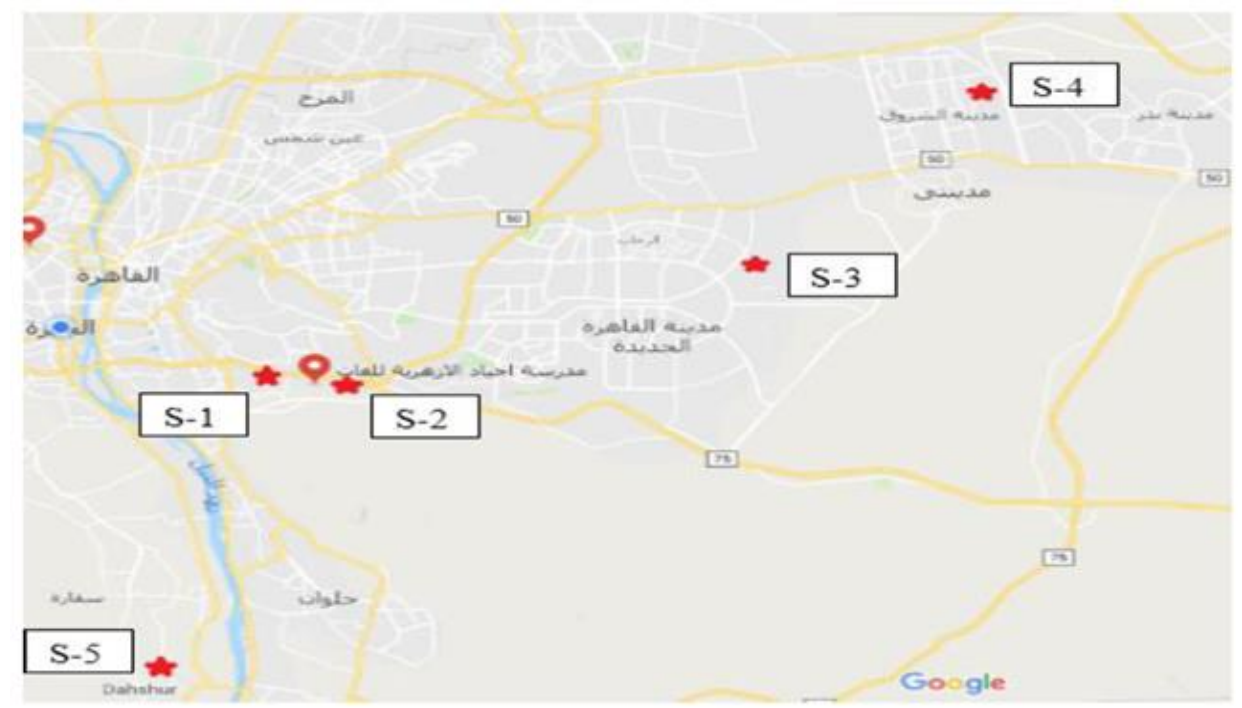

Fig. 1. Map of studied soil locations

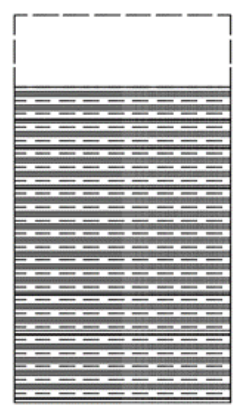

Test 1

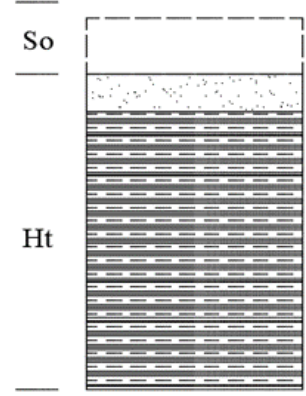

Test 2

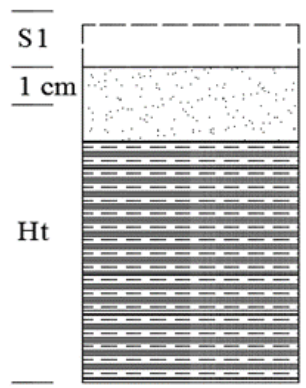

Test 3

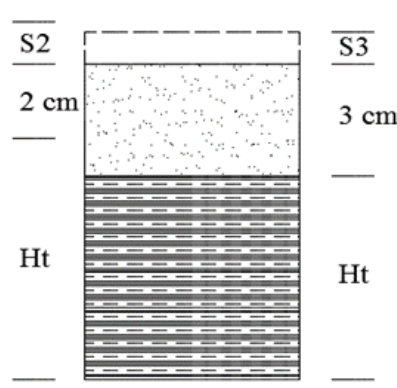

Test 4

Fig. 2. Model of replacement layer

Table 2. Physical properties of the studied soil

\begin{tabular}{|c|c|c|c|c|c|c|c|c|}
\hline \multirow{2}{*}{$\begin{array}{c}\text { Sample } \\
\text { No. }\end{array}$} & \multicolumn{7}{|c|}{ Property } & \multirow[b]{2}{*}{ USCS } \\
\hline & $\begin{array}{l}\mathrm{W}_{\mathrm{n}}, \\
(\%)\end{array}$ & $\begin{array}{c}\left(\gamma_{\text {nata }}\right) \\
\mathrm{gm} / \mathrm{cm}^{3}\end{array}$ & $\mathrm{G}_{\mathrm{s}}$ & $\begin{array}{l}\text { LL, } \\
(\%)\end{array}$ & PL, (\%) & SL, $(\%)$ & PI, (\%) & \\
\hline S-1 & 12.43 & 1.74 & 2.65 & 80.69 & 41.25 & 13.5 & 39.44 & $\mathrm{MH}$ \\
\hline S-2 & 11.95 & 1.73 & 2.65 & 73.44 & 38.2 & 12.4 & 35.24 & $\mathrm{MH}$ \\
\hline $\mathrm{S}-3$ & 10.25 & 1.75 & 2.62 & 84.62 & 35 & 13.02 & 49.62 & $\mathrm{CH}$ \\
\hline S-4 & 9.15 & 1.77 & 2.71 & 93.96 & 40 & 14.2 & 53.96 & $\mathrm{CH}$ \\
\hline$S-5$ & 12.55 & 1.72 & 2.66 & 48.66 & 28 & 15.06 & 20.66 & CL-ML \\
\hline
\end{tabular}

\subsection{Particle Size Distribution}

Grain size distribution curves of the studied soil samples by hydrometer sedimentation analysis are plotted and summarized in Fig. 3. Moreover, Table 3 represent the percentage of particle contents. Refereeing to the results of particle distributions and contents, it is clear that:

- The clay particles percentage are ranged between "16\%" and "51\%". Where, soil S-5 and S-3 have the lowest and the highest values respectively. So, silt particles content are ranged between "84\%" to "49\%". Where, soils S-1, S-2 and S-4 are classified as Clayey Silt. While, the soils S-3 and S-5 are classified Silty Clay.
Table 3. Grain Size Distribution results

\begin{tabular}{|c|c|c|}
\hline \multirow{2}{*}{ Sample No. } & \multicolumn{2}{|c|}{ Content percent } \\
\cline { 2 - 3 } & Silt, (\%) & Clay, (\%) \\
\hline S-1 & 73 & 27 \\
\hline S-2 & 72 & 28 \\
\hline S-3 & 49 & 51 \\
\hline S-4 & 58 & 42 \\
\hline S-5 & 84 & 16 \\
\hline
\end{tabular}

\subsection{Compaction Results}

Standard proctor test results of the studied soils are indicated in Fig. 4. The compaction results as maximum dry density $\left(\gamma_{\text {dmax. }}\right)$ and optimum moisture content (OMC) are listed in Table 4, it is clear that: 


\section{E. A. El-Kasaby, A. A. Easa, M. F. Abd-Elmagied, Mohammed G. El-Abd "EXPERIMENTAL ..."}

- The values of OMC are ranged between "18\%" and "24\%". While, soil sample S-5 has the highest OMC and soil sample S-2 has the lowest OMC.

- The values of $\gamma_{\mathrm{dmax}}$. are ranged between 1.62 $\mathrm{gm} / \mathrm{cm}^{3}$ to $1.70 \mathrm{gm} / \mathrm{cm}^{3}$. While, soil sample $\mathrm{S}-4$ has the highest $\gamma_{\mathrm{dmax}}$, and soil sample $\mathrm{S}-5$ has the lowest $\gamma_{\text {dmax. }}$.

Table 4. Compaction results for the studied soils

\begin{tabular}{|c|c|c|}
\hline \multirow{2}{*}{ Sample No. } & \multicolumn{2}{|c|}{ Property } \\
\cline { 2 - 3 } & OMC, $(\%)$ & $\gamma_{\text {dmax. }}\left(\mathrm{gm} / \mathrm{cm}^{3}\right)$ \\
\hline S-1 & 18.50 & 1.66 \\
\hline S-2 & 18.00 & 1.65 \\
\hline S-3 & 22.20 & 1.67 \\
\hline S-4 & 22.50 & 1.70 \\
\hline S-5 & 24.00 & 1.62 \\
\hline
\end{tabular}

\subsection{Clay Minerals}

X-ray diffraction patterns of both Oriented, Glycolated and Heated as case of sample preparation are shown in Figs. 5 and 6. Accordingly, the determined mineral percentage are presented in Table 5. It is evident that:

- All samples contained Kaolinite (K), Illite (I) and Montmorillonite (M) minerals. The expansive nature can be attributed to the considerable amount of the Montmorillonite (M) mineral present in all soil samples.

- The values of Kaolinite (K), Illite (I) and Montmorillonite (M) percentage are ranged between $16.06 \%$ - $41.08 \%, 0.55 \%-4.51 \%$ and $54.69 \%-82.55 \%$ respectively.
Table 5. XRD percentages results

\begin{tabular}{|c|c|c|c|}
\hline \multirow{2}{*}{ Sample No. } & \multicolumn{3}{|c|}{ Clay minerals percentage } \\
\cline { 2 - 4 } & $\mathrm{K}$ & $\mathrm{I}$ & $\mathrm{M}$ \\
\hline S-1 & 16.06 & 1.39 & 82.55 \\
\hline S-2 & 31.27 & 4.51 & 64.22 \\
\hline S-3 & 31.92 & 4.19 & 63.15 \\
\hline S-4 & 31.13 & 0.55 & 68.86 \\
\hline S-5 & 41.08 & 4.04 & 54.69 \\
\hline
\end{tabular}

\subsection{SEM Analysis Results}

The SEM research performed on the studied soil to understanding the influences of structure on soil swelling behavior. Figs. 7 and 8 show that the morphology of the five tested samples, mainly formed of varying size $(10-5 \mu \mathrm{m})$. It is clear that:

- The presence of montmorillonite is confirmed by SEM photomicrographs of the five tested samples along the layers, showing clear flakes morphology. The flocculated clay particles are arranged in an arching skeleton enclosing large voids.

- Soil sample S-1 has the highest percent of montmorillonite and soil sample S-5 the lowest percent of montmorillonite. The results of SEM are approved with the results of clay mineral percent as indicated in Table 5.

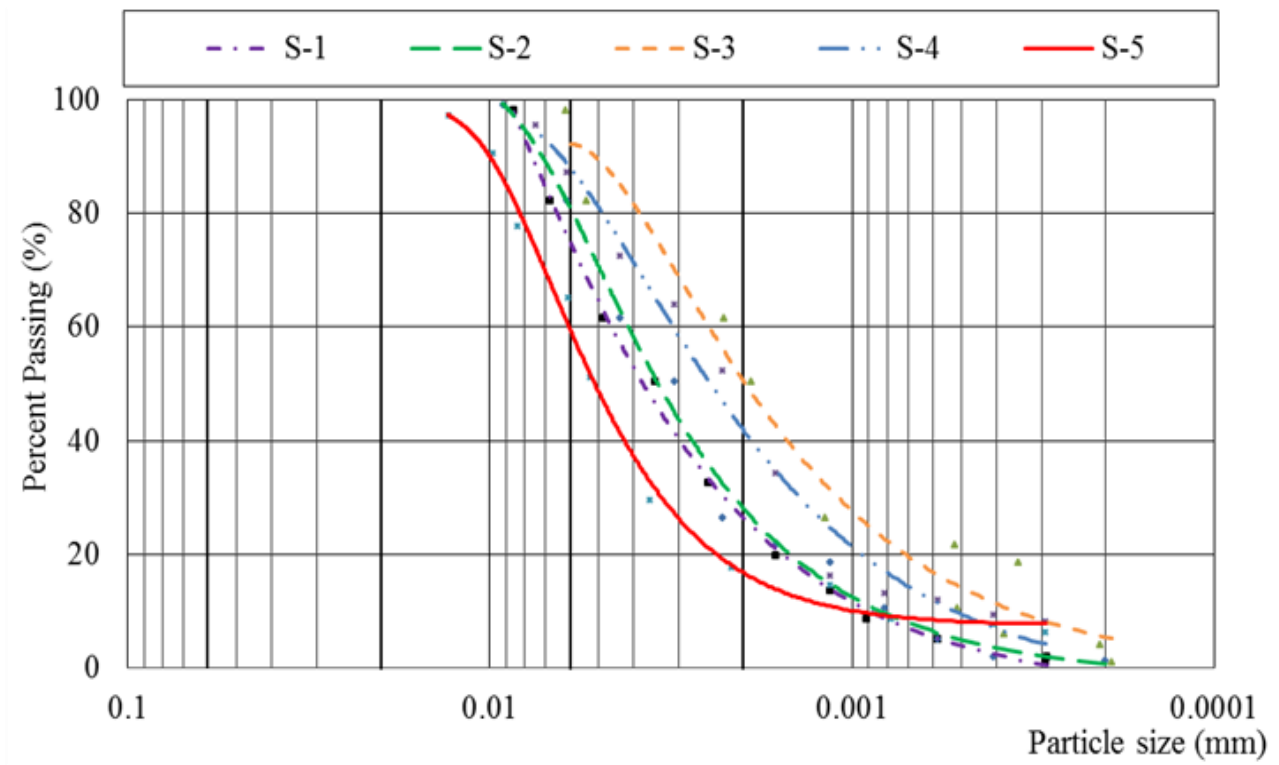

Fig. 3. Particle size distribution curves 


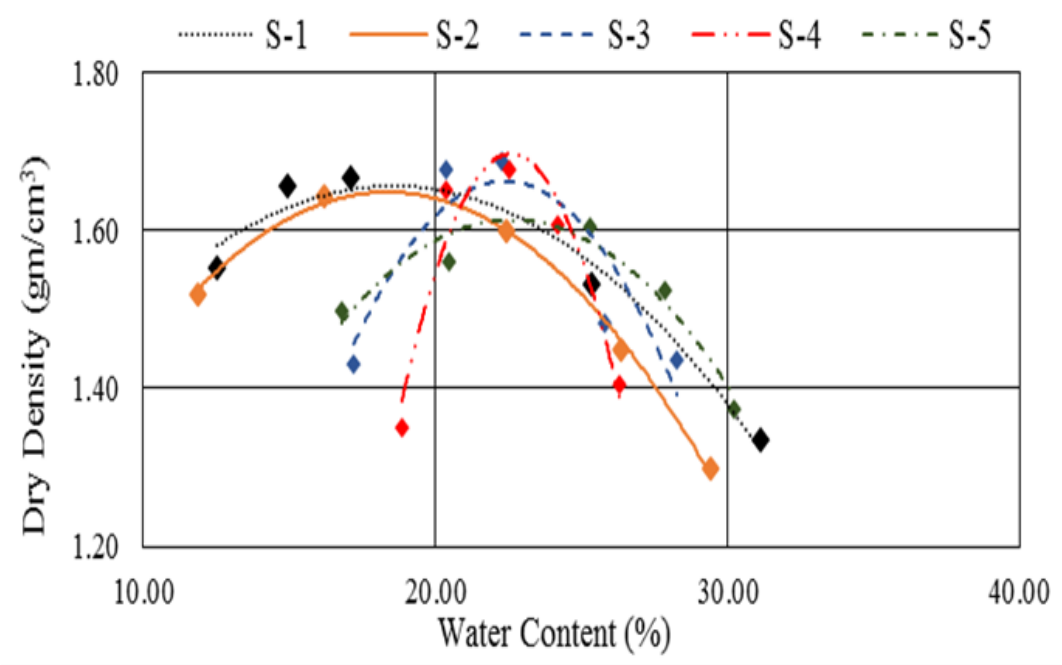

Fig. 4. Standard Proctor tests results

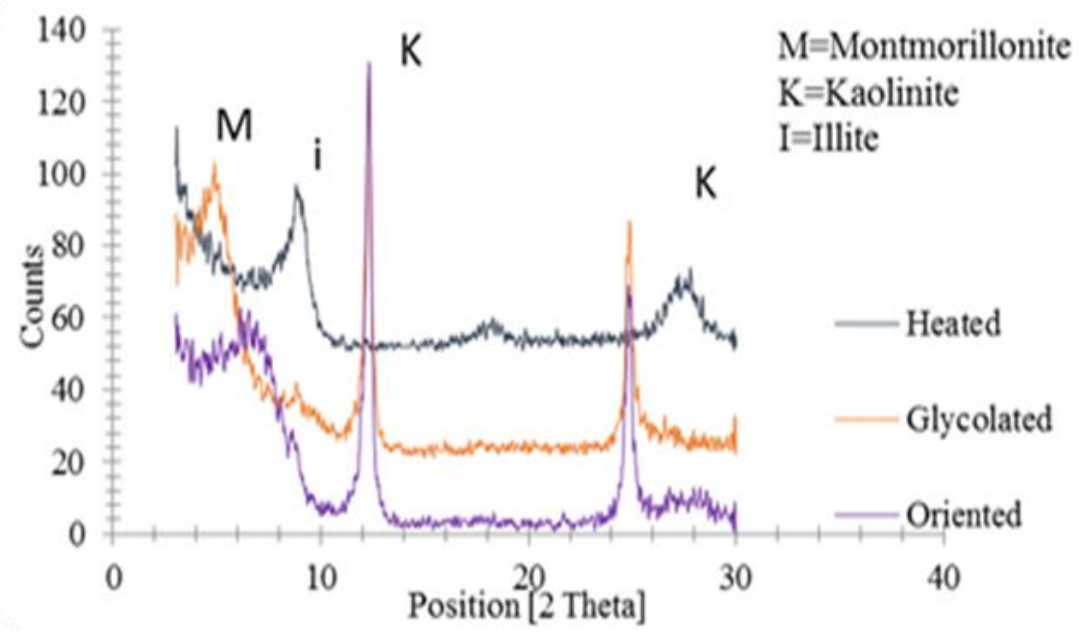

Fig. 5. X-ray diffraction patterns for S-1

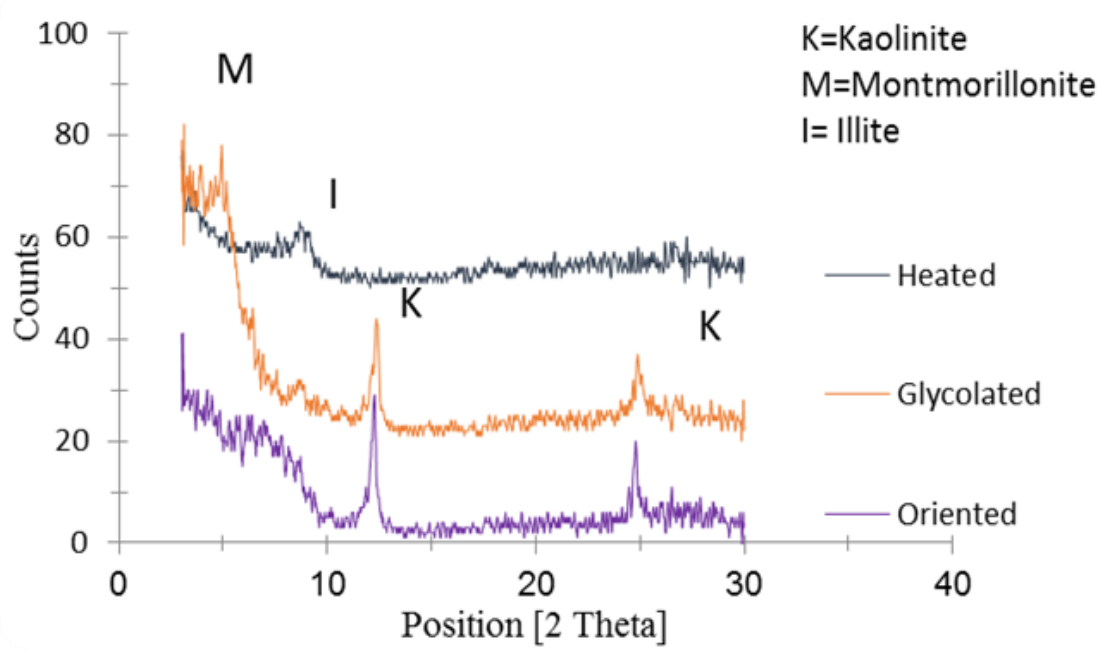

Fig. 6. X-ray diffraction patterns for S-5 


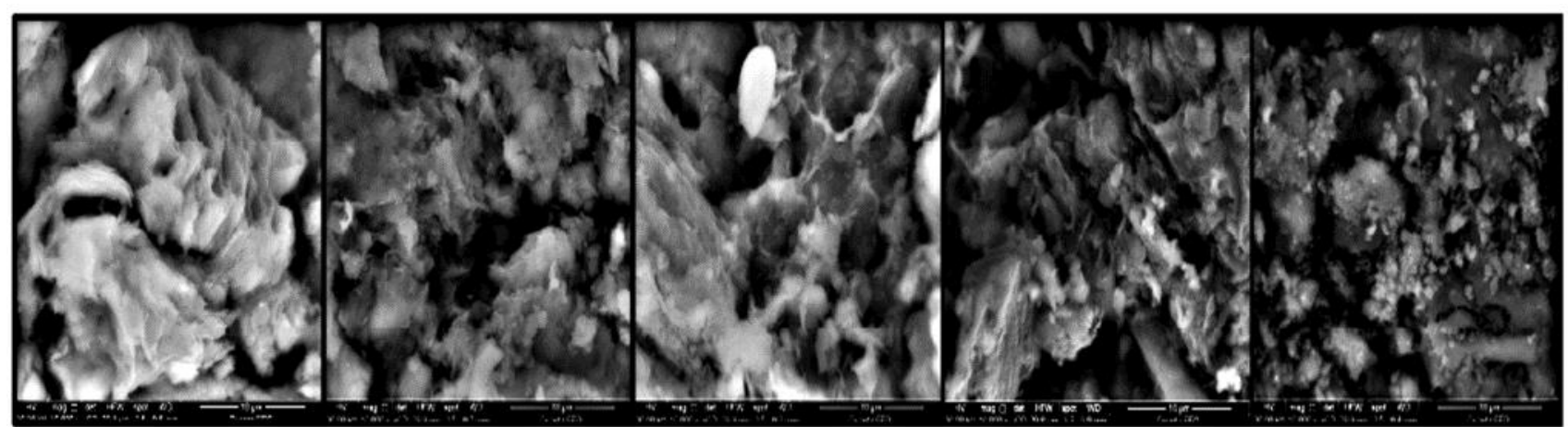

Fig. 7. Photomicrographs for soils S-1, S-2, S-3, S-4 and S-5 respectively (Scale $10 \mu \mathrm{m}$ )

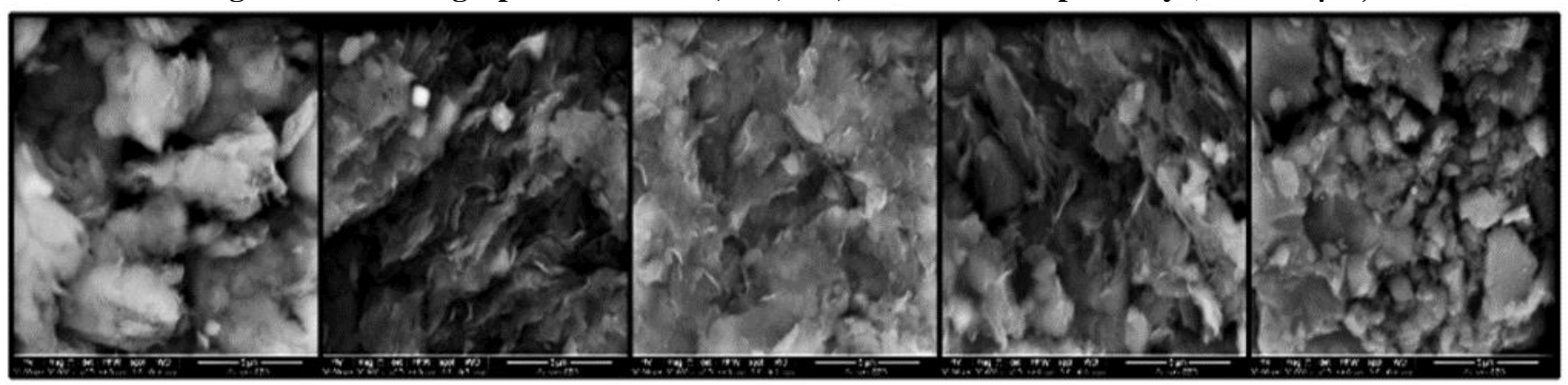

Fig. 8. Photomicrographs for soils S-1, S-2, S-3, S-4 and S-5 respectively (Scale $5 \mu \mathrm{m}$ )

3.6 Swelling Pressure and Free Swell

The obtained results of different pressure method are tabulated in table 6 . The values of swelling pressure (SP) at zero swell obtained by extending the curves, Fig. 9. The results of SP and the values of free swell (FS) are listed in Table 7. It is noted that:

- The values of swelling pressure (SP) are ranged between $1.88 \mathrm{~kg} / \mathrm{cm}^{2}$ to $3.34 \mathrm{~kg} / \mathrm{cm}^{2}$. While, soil sample S-4 has the highest swelling pressure value and soil sample $\mathrm{S}-5$ has the lowest swelling pressure value.

- Free swell (FS) are ranged between $100 \%$ and $320 \%$. While, soil sample S-4 has the highest FS value and soil sample S-5 has the lowest FS value.

Table 6. Swell percent results for different stresses

\begin{tabular}{|c|c|c|c|c|c|}
\hline \multirow{2}{*}{ Stress, Kg/cm } & \multicolumn{5}{|c|}{ Swell percent, \% } \\
\cline { 2 - 6 } & $\mathrm{S}-1$ & $\mathrm{~S}-2$ & $\mathrm{~S}-3$ & $\mathrm{~S}-4$ & $\mathrm{~S}-5$ \\
\hline 0.25 & 18 & 14 & 15 & 17 & 10 \\
\hline 0.509 & 14 & 10 & 12 & 13 & 7 \\
\hline 1.02 & 7 & 6 & 7 & 8 & 3 \\
\hline 1.52 & 4 & 2.5 & 3 & 5 & 1 \\
\hline
\end{tabular}

Table 7. Swelling pressure and free swell results

\begin{tabular}{|c|c|c|}
\hline \multirow{2}{*}{ Sample No. } & \multicolumn{2}{|c|}{ Property } \\
\cline { 2 - 3 } & $\mathrm{SP},\left(\mathrm{Kg} / \mathrm{cm}^{2}\right)$ & $\mathrm{FS},(\%)$ \\
\hline $\mathrm{S}-1$ & 2.56 & 200 \\
\hline $\mathrm{S}-2$ & 2.46 & 200 \\
\hline $\mathrm{S}-3$ & 2.71 & 220 \\
\hline $\mathrm{S}-4$ & 3.34 & 320 \\
\hline S-5 & 1.88 & 100 \\
\hline
\end{tabular}

The results of SP at zero swell and the values of FS are listed in Table 7. Accordingly, it clears that:
- The determined values of SP and FS are approved with the results of clay mineral percent as indicated in Table 5.

- In spite of the soil sample S-4 has the highest (M) percent but it hasn't highest SP and FS.

- The values of SP and FS are agreed with the values of LL and PI. Where, sample S-4 of high SP and FS are proportion with LL and PI of the same soil sample.

\subsection{Cation Exchange Capacity}

Data in table 8 indicate the values of cation exchange capacity (CEC) of the studied soils. It is evident that:

- The values of cation exchange capacity (CEC) are ranged between $26.3 \mathrm{meq} / 100 \mathrm{~g}$ and 90.4 $\mathrm{meq} / 100 \mathrm{~g}$ with average value $70.26 \mathrm{meq} / 100 \mathrm{~g}$.

Table 8. Cation exchange capacity results

\begin{tabular}{|c|c|}
\hline Sample No. & CEC(meq/100g) \\
\hline S-1 & 90.4 \\
\hline S-2 & 80.2 \\
\hline S-3 & 67.8 \\
\hline S-4 & 86.6 \\
\hline S-5 & 26.3 \\
\hline
\end{tabular}

Figure 10 shows the relationship between CEC and Montmorillonite percentage $(\% \mathrm{M})$. While, the relationship between CEC and PI is indicated in Fig. 11. From these figures, it is clear that:

- Cation exchange capacity (CEC) is directly proportion with montmorillonite percentage $(\% \mathrm{M})$. Also, CEC is directly proportion with free swell (FS). 


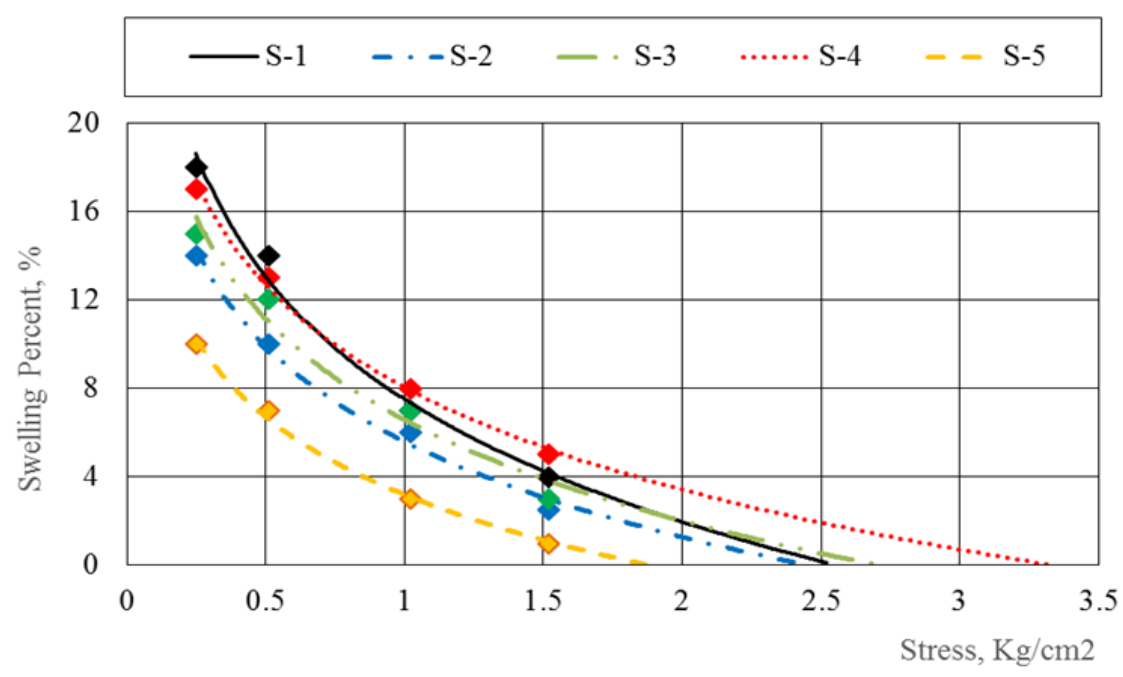

Fig. 9. Swelling Pressure Test Results

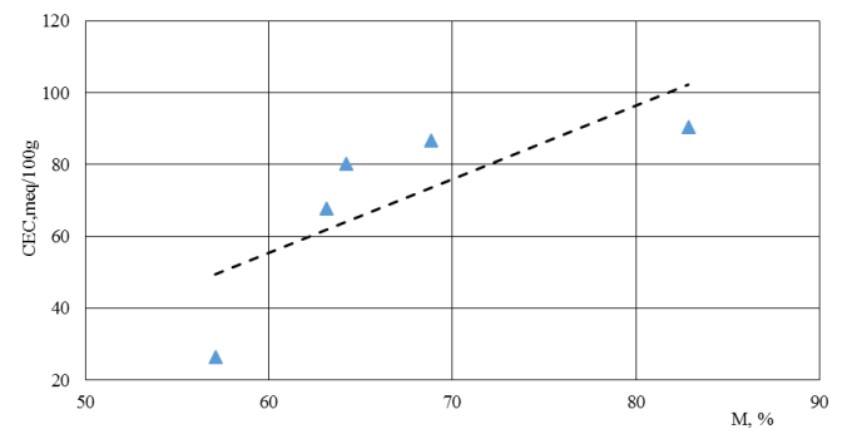

Fig. 10. Correlation of C.E.C with M\%

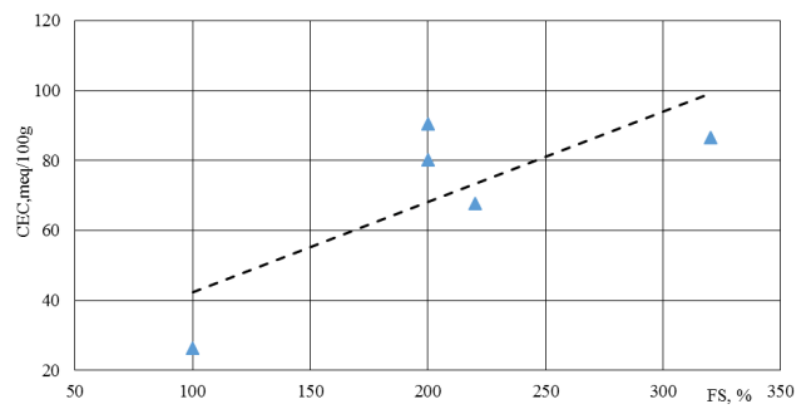

Fig. 11. Correlation of C.E.C with FS\%

\subsection{Replacement Layers}

The obtained results of free swell according to the tests using the simple model which mentioned in Fig. 1 are tabulated in Table 9. At variant thickness of replacement layer, Fig. 12 shows the relationship between the measured swell versus the elapsed time of soaking. From these results, it is clear that:

- The values of swell are ranged between $30.8 \mathrm{~mm}$ to $22.56 \mathrm{~mm}$. The highest swell is occurred at zero replacement thickness and the lowest at $3 \mathrm{~cm}$ replacement thickness. So, swell reduction ratio values ( $\mathrm{R} \%)$ of expansive soil layer thickness are shown in Fig. 13.

- The results of swell reduction $(\mathrm{R} \%)$ are agreed with the results of [15].
Table 9. Free swell and reduction values for different replacement thickness

\begin{tabular}{|c|c|c|c|c|}
\hline $\begin{array}{l}\text { Test } \\
\text { No. }\end{array}$ & $\begin{array}{c}\text { Thickness } \\
\text { of clay, } \\
(\mathrm{cm})\end{array}$ & $\begin{array}{c}\text { Thickness of } \\
\text { replacement, } \\
(\mathrm{cm})\end{array}$ & $\begin{array}{c}\text { The swelling } \\
\text { at the end of } \\
\text { test, }(\mathrm{cm})\end{array}$ & $\begin{array}{c}\mathrm{R}, \\
(\%)\end{array}$ \\
\hline 1 & 11.92 & 0 & 3.08 & 0 \\
\hline 2 & 10.92 & 1 & 2.82 & 8.57 \\
\hline 3 & 9.92 & 2 & 2.44 & 20.81 \\
\hline 4 & 8.92 & 3 & 2.26 & 26.76 \\
\hline
\end{tabular}

Where, $\mathrm{R} \%$ swelling reduction ratio: $\mathrm{R} \%=\left[\left(\mathrm{S}_{0^{-}}\right.\right.$ $\left.\mathrm{S}_{\mathrm{i}} / \mathrm{S}_{\mathrm{o}}\right] \times 100, \mathrm{~S}_{\mathrm{o}}=$ maximum swell in cm without any replacement and $S_{i}=$ swell at variable replacement layer thickness. 


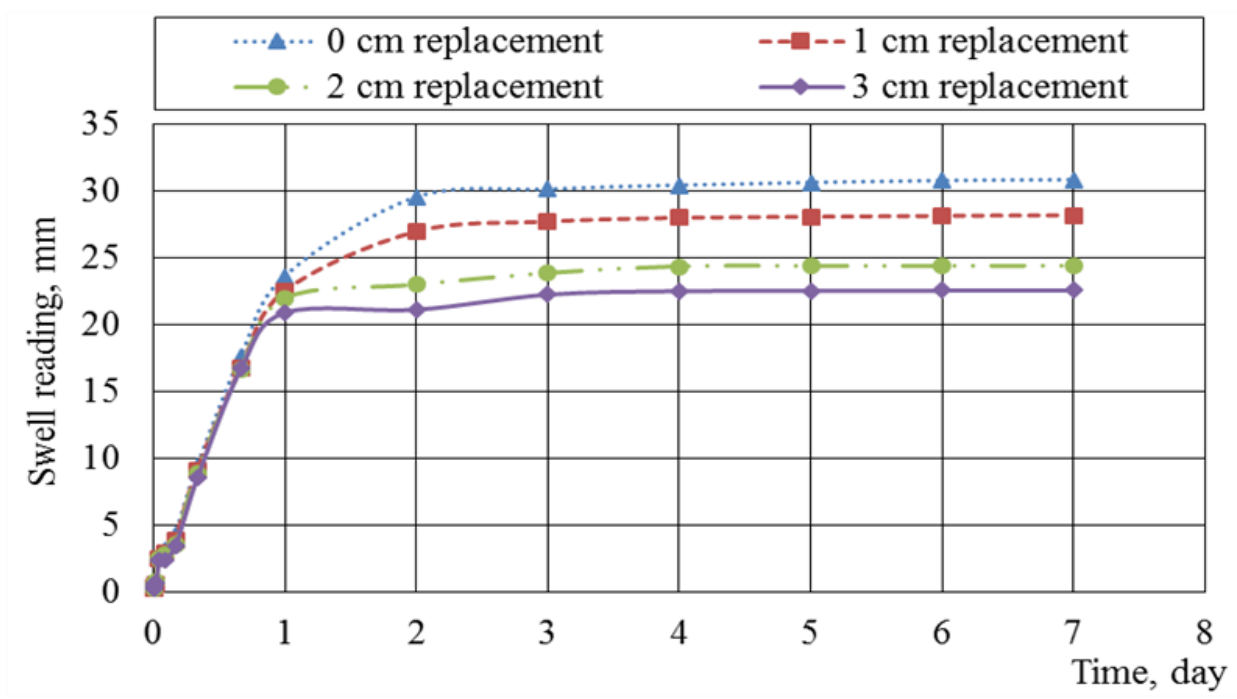

Fig. 12. Correlation of time with swell reading

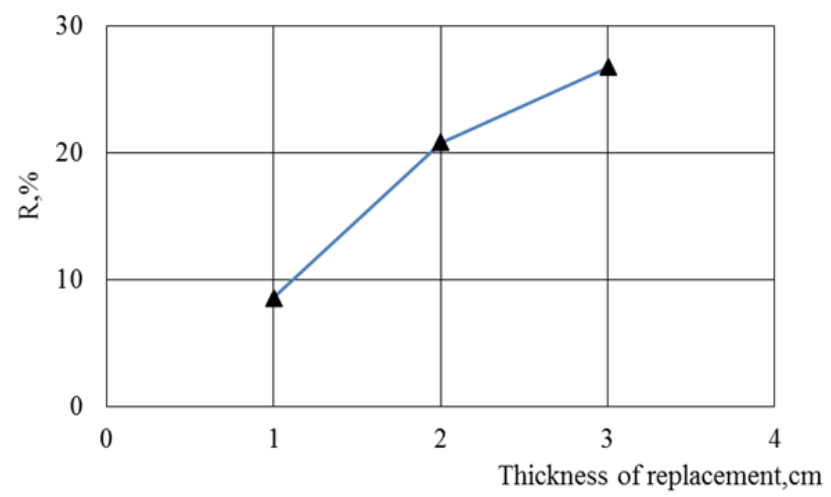

Fig. 13. Correlation of reduction ratio with thickness of replacement

\section{Discussion}

4.1 Effect of Free Swell, Plasticity Index and Montmorillonite Percentage on Swelling Pressure

By using data-fit software to correlate swelling pressure (SP) with Montmorillonite percentage $(\mathrm{M}, \%)$, plasticity index (PI,\%) and free swell (FS,\%) for the studied soils, an empirical formula can deduced as:

$$
\mathrm{SP}=\mathrm{A} \times \mathrm{FS}+\mathrm{B} \times \mathrm{P} . \mathrm{I}+\mathrm{C} \times \mathrm{M}
$$

Where, $\mathrm{A}, \mathrm{B}$ and $\mathrm{C}=$ constants of values 0.0075 , 0.0065 and 0.0097 respectively, and $\mathrm{SP}$ by $\mathrm{kg} / \mathrm{cm}^{2}$

For application, Equation (1) is used to indicate the relations between swelling pressure and plasticity index at variant values of free swell and constant value of Montmorillonite percentage $(\mathrm{M}=60 \%)$ as shown in Fig. 14. It clears that, swelling pressure is slightly direct proportion with free swell, Plasticity index.

The comparison between the measured SP values and the predicted values is given in Fig. 15. Good correlation is obtained in the prediction of SP as the $\begin{array}{lll}\text { corresponding } \mathrm{R} \text {-squared reaches } & 0.84 \text {. }\end{array}$

\subsection{Effect of Replacement Layer on Swelling Behavior}

By using data-fit software to correlate replacement layer thickness $\left(\mathrm{T}_{\text {rep. }}\right)$ with swell reduction ratio $(\mathrm{R}, \%)$ for the studied soil, an empirical formula can deduced as:

$$
\mathrm{R} \%=\mathrm{A}+\mathrm{B} \times\left(\mathrm{T}_{\text {rep. }} / \mathrm{H}_{\mathrm{t}}\right)^{2.50}
$$

Where, $\left.\mathrm{R} \%=\left[\mathrm{S}_{\mathrm{o}}-\mathrm{S}_{\mathrm{i}}\right) / \mathrm{S}_{\mathrm{o}}\right] * 100, \mathrm{~A}$ and $\mathrm{B}=$ constants of values 7.33 and 0.0048 respectively and $\mathrm{Ht}=$ Total thickness of swelling layer.

For application, Equation (2) is used to indicate the relations between swelling reduction ratio with replacement thickness for suggested variant values of $\mathrm{H}_{\mathrm{t}}(\mathrm{m})$ as shown in Fig. 15. In addition to that, Fig. 16 indicates the relationship between total thickness of swelling layer and replacement layer thickness for suggested variant values of $\mathrm{R} \%$.

Referring to the estimated results as Fig. 16 and 17, it evident that:

- Swelling reduction ratio ( $\mathrm{R} \%)$ is directly proportion with replacement layer thickness $\left(\mathrm{T}_{\text {rep. }}\right)$ at constant swelling layer thickness.

- Replacement layer thickness $\left(\mathrm{T}_{\text {rep. }}\right)$ is directly proportion with swelling layer thickness $\left(\mathrm{H}_{\mathrm{t}}\right)$ at the same swelling reduction ratio value. 
According to the aforementioned results, strong instruction, invitation, information and recommendations must be given engineers, peoples and contractors to avoid the harmful effect of swelling soil on foundations and underground construction. Also, it is recommended to continue in-situ and laboratory studies on engineering properties of soil in Egyptian desert surrounding Cairo city are strongly required for future developments.

Results of the present study are compared with the results of EL-Nahhas et al., (1998). Where, Figs. 18 and 19 represent the comparison of reduction ratio $(\mathrm{R}$ $\%$ ) against replacement thickness $\left(\mathrm{T}_{\text {rep. }}\right)$ at swelling layer thickness of $1.80 \mathrm{~m}$ and $6.00 \mathrm{~m}$ respectively. It is evident that:

- When reduction ratio ( $\mathrm{R} \%$ ) varied from $0 \%$ to $63 \%$, the replacement thickness values of present study agreed with that mentioned by EL-Nahhas et al., (1998). While if reduction ratio ( $\mathrm{R} \%)$ increased than $63 \%$, the replacement thickness values of the present study decreased than the results of EL-Nahhas et al., (1998) at swelling layer thickness of $1.80 \mathrm{~m}$.

- At reduction ratio ( $\mathrm{R} \%$ ) from $0 \%$ to $46.5 \%$, the replacement thickness values of present study agreed with that mentioned by EL-Nahhas et al., (1998). While, with the increase of reduction ratio ( $\mathrm{R} \%$ ) than $46.5 \%$ the replacement thickness values of the present study decreased than the results of EL-Nahhas et al., (1998) at swelling layer thickness of $6.00 \mathrm{~m}$.

- The good agreement between present study and the results of EL-Nahhas et al., (1998) was occurred at the reduction ratio ( $\mathrm{R} \%$ ) of $22 \%$ and $35 \%$ at swelling layer thickness of $1.80 \mathrm{~m}$ and $6.00 \mathrm{~m}$ respectively.

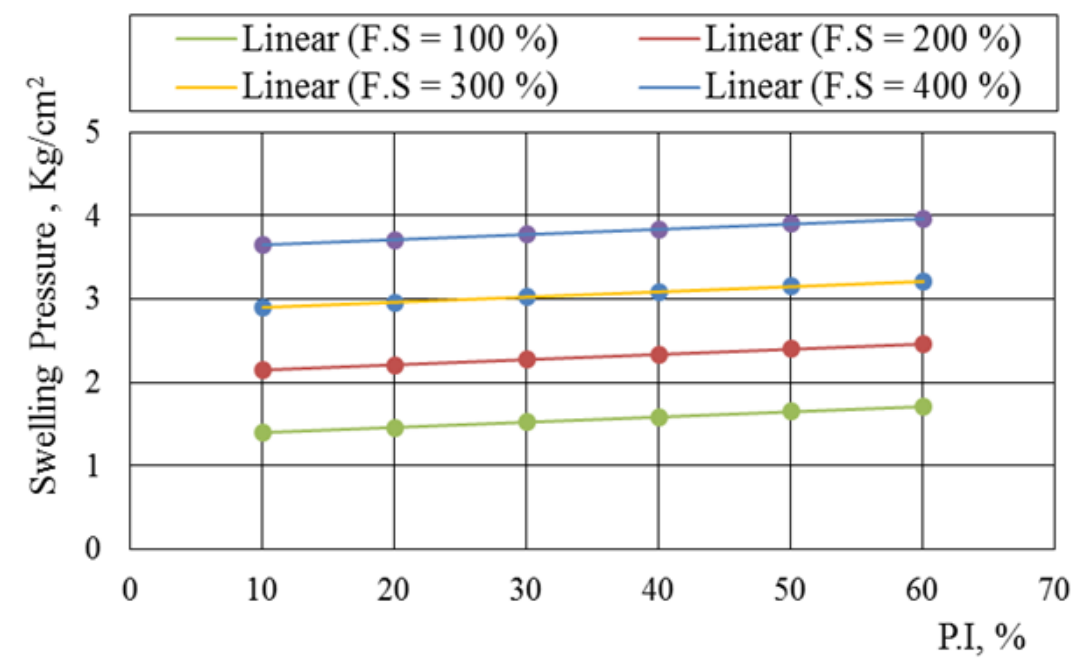

Fig. 14. Correlations of Plasticity index with Swelling Pressure at $(M=60 \%)$

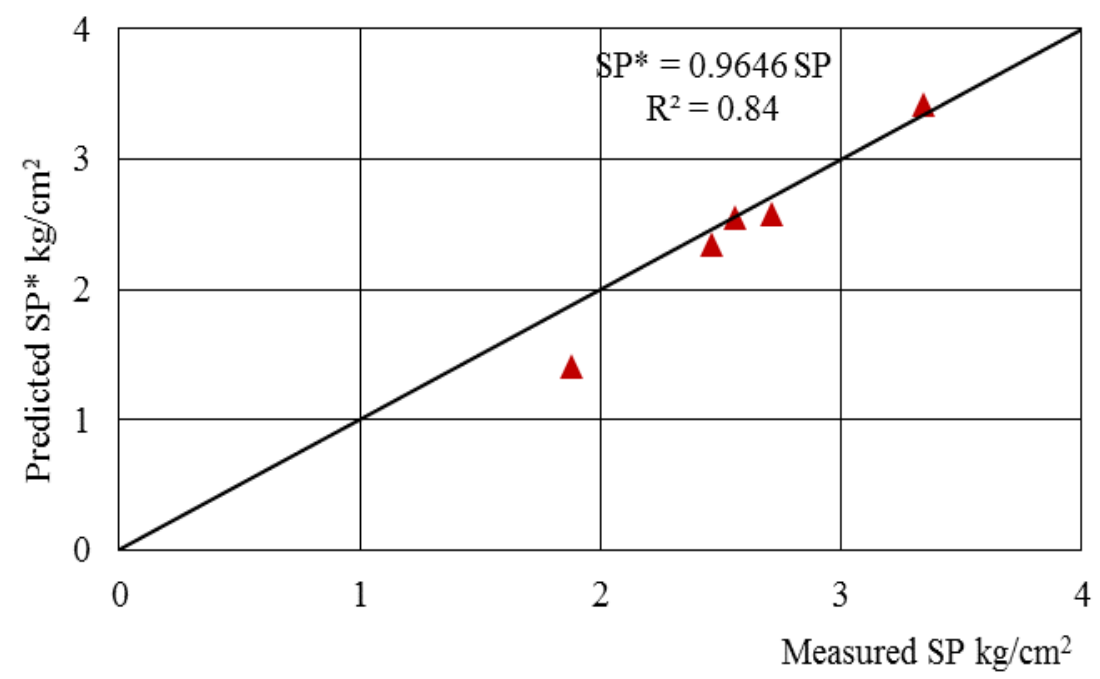

Fig. 15. The relationship between measured and predicted swelling pressure 
E. A. El-Kasaby, A. A. Easa, M. F. Abd-Elmagied, Mohammed G. El-Abd "EXPERIMENTAL ...”"

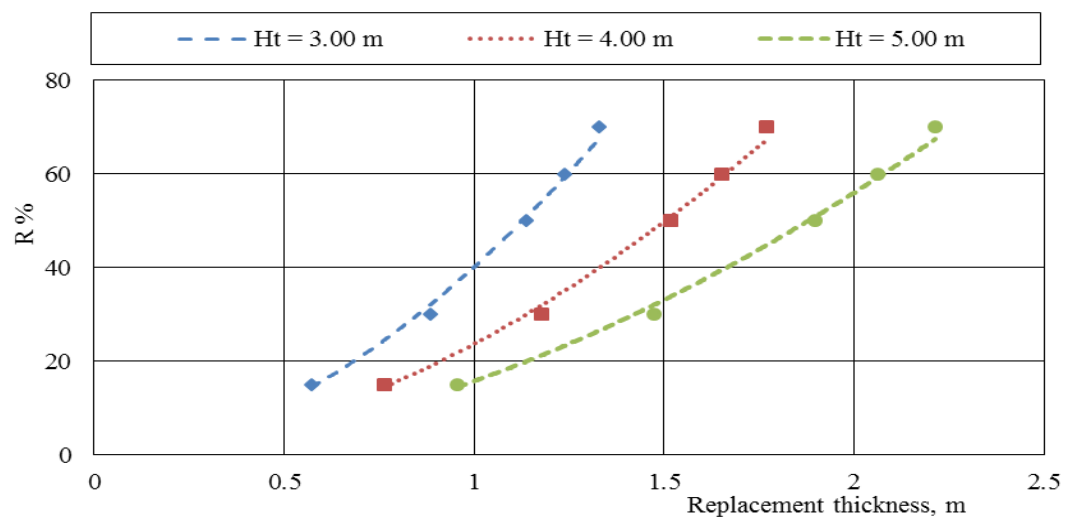

Fig. 16. Relation of replacement thickness with swell reduction percentage

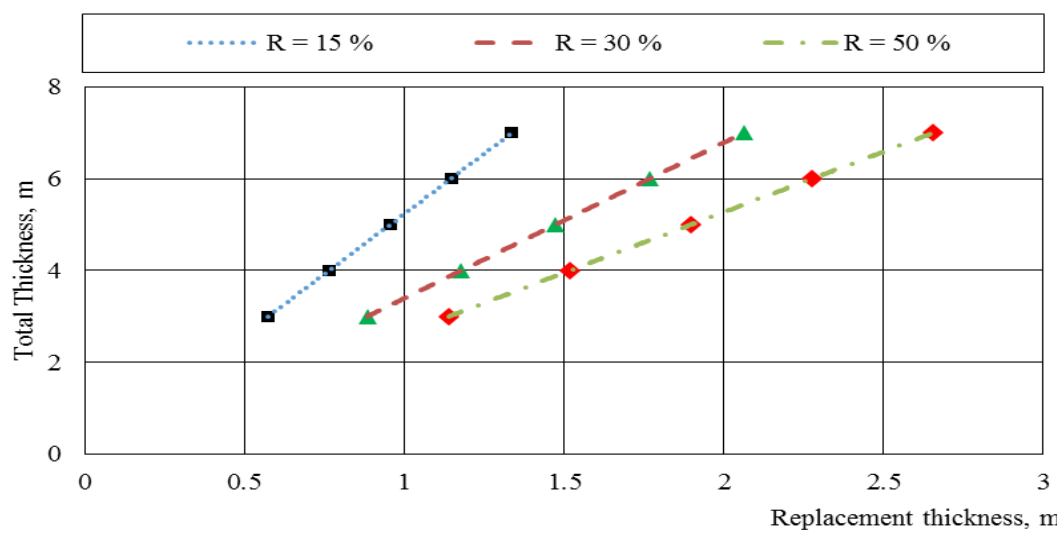

Fig. 17. Relation of replacement thickness with total thickness of swelling layer

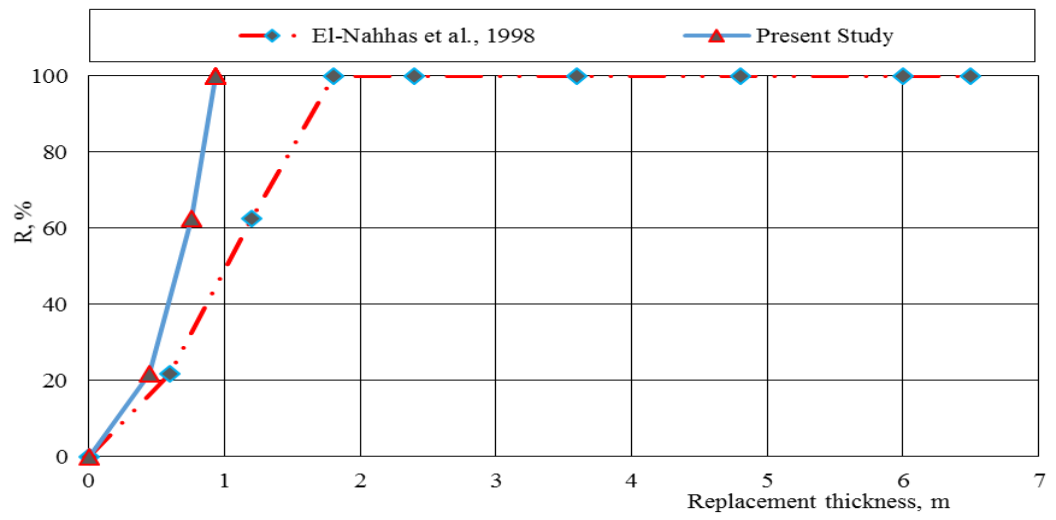

Fig. 18. Comparison between deduced empirical equation and EL-Nahhas et al., $1998(\mathrm{H}=1.80 \mathrm{~m})$

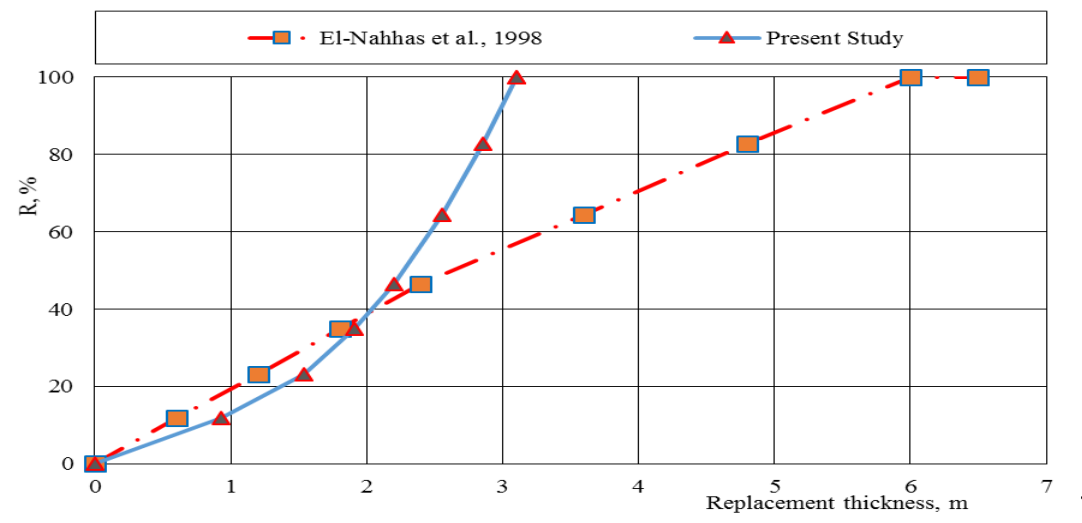

Fig. 19. Comparison between deduced empirical equation and EL-Nahhas et al., $1998(\mathrm{H}=6.00 \mathrm{~m})$ 


\section{Conclusion}

Properties of expansive soils founded in Egyptian desert of new urban areas surrounding Cairo city were experimentally studied. The following conclusions can be drawn:

- Five expansive soil samples were studied, its natural moisture content $\left(\mathrm{w}_{\mathrm{n}}\right)$ and $\left(\gamma_{\text {nat. }}\right)$ are ranged between $9.15 \%$ to $12.55 \%$ and 1.72 $\mathrm{gm} / \mathrm{cm}^{3}$ to $1.77 \mathrm{gm} / \mathrm{cm}^{3}$, respectively. The values of liquid limit (LL) and (PL) are ranged between $48.66 \%$ to $93.96 \%$ and $28 \%$ to $41.25 \%$, respectively.

- The soils from El Maadi El Gedida are classified as $\mathrm{MH}$, but, soil from Dahshur is classified as ML. Moreover, soils from New Cairo and Alshrouk are classified as $\mathrm{CH}$. The value of shrinkage Limit (SL) is ranged between "12.4\%" to " $15.06 \% "$. The value of specific gravity is approximately closed around 2.67.

- The amount of clay particles are ranged between "16\%" to "51\%". So, silt particles content are ranged between "84\%" to "49\%". The amount of

- Montmorillonite mineral is ranged between "57.10\%" to "82.85\%". Also, Cation exchange capacity values are ranged between "26.30 meq/100g" to "90.40 meq/100g".

- The compaction results OMC , $\gamma_{\mathrm{dmax}}$ are ranged between $18 \%$ to $24 \%$ and $1.70 \mathrm{gm} / \mathrm{cm}^{3}$ to 1.62 $\mathrm{gm} / \mathrm{cm}^{3}$, respectively.

- The values of swelling pressure (SP) are ranged between $1.88 \mathrm{~kg} / \mathrm{cm}^{2}$ to $3.34 \mathrm{~kg} / \mathrm{cm}^{2}$. As well as, free swell values are ranged between "100\%" to "320\%".

- Relation between swelling pressure against the plasticity index, free swell and Montmorillonite percentage in the studied soils is expressed in empirical formula given as:

$\mathrm{SP}=7.5 \times 10^{-3} \mathrm{FS}+6.5 \times 10^{-3} \mathrm{P} . \mathrm{I}+9.7 \times 10^{-3} \mathrm{M}$

- The relationship of swelling reduction ratio $(\mathrm{R} \%)$ with replacement layer thickness (Trep.) is suggested by the following empirical formula: $\mathrm{R} \%=7.33+4.8 \times 10^{-3}\left(\mathrm{~T}_{\text {rep. }} / \mathrm{H}_{\mathrm{t}}\right)^{2.50}$

- The good agreement between the results of the present study and the results of EL-Nahhas et al., 1998 was occurred.

\section{References}

[1] Azam S.,Shah I.,Raghunandan M. and Ito M., "Study on Swelling Properties of an Expansive Soil Deposit in Saskatchewan, Canada", Bulletin of Engineering Geology and the Environment, Canada, Vol. 72, pp. 25-35, (2013).

[2] Lin, B. "A Comprehensive Investigation on Microscale Properties and Macroscopic Behavior of Natural Expansive Soils", Ph.D. Dissertation, University of Oklahoma, Norman, Oklahoma, USA, (2012).

[3] Chen, F.H., "Foundations on Expansive Soils", Elsevier Scientific Publishing Company, Amsterdam-Oxford-New York, (1975).
[4] El-Kasaby, E.A. "Foundation on Swelling Clay", Master Science Thesis, Department of Civil Engineering, University of Assuit, Egypt, 166 pp., (1978).

[5] Nelson, J.D. and Miller, D.J., "Expansive Soils: Problem and Practice in Foundation and Pavement Engineering", John Wiley and Sons, New York, (1992).

[6] Abu Zeid, M.M., El Nahhas, F., Dowidar, H., and Hashem, W. "Petrology and Engineering Geology of El Obour City", Middle East Research Center, Ain Shams Univ., Earth Science Series, Vol. 18, pp. 81-105, (2004).

[7] Hana H. Adem, Sai K. Vanapalli, S. "Review of Methods for Predicting In-Situ Volume Change Movement of Expansive Soil Over Time", Journal of Rock Mechanics and Geotechnical Engineering, Elsevier publishers, Vol. 7, pp. 7386, (2014).

[8] Muntohar, A.S. and Hashim, R., "Properties of Engineered Expansive Soils", Proceedings of the First Technical Postgraduate Symposium, University of Malaya, Malaysia, pp. 272 - 276, (2002).

[9] BS 60335-2-81. "British Standard Methods of Testing for Soils for Civil Engineering Purposes", British Standards Institution, London, Great Britain, (2012).

[10] Lu Lu, "A Simple Technique For Estimating The 1-D Heave of Natural Expansive Soils", Master science thesis, Department of Civil Engineering, University of Ottawa, Canada, (2010).

[11] Dhakal, G.P. "Mineralogy and Geotechnical Properties of Argillaceous Clastic Rocks", Ph.D. dissertation, Division of Environment and Resources Engineering, Faculty of Engineering, Hokkaido University, Japan, (2001).

[12] Easa, AA and El-darder, M.E. "In-Situ Investigation of Mineralogical and Chemical Properties of Clayey Soil Contaminated with Wastewater", Engineering research journal, Helwan University, vol. 84, pp. 150-161, (2002).

[13] Srinivas K., Prasad D.S.V. and Rao3 Er.V.K.L. "A Study on Improvement of Expansive Soil by Using CNS (Cohesive Non Swelling) layer", International Journal of Innovative Research in Technology, India, Vol. 3, pp. 54-60, (2016).

[14] Murray, H.H. "General Overview of Traditional and New Applications for Kaolin, Smectite and Palygorskite", Applied Clay Science Vol. 17, pp. 207-221, (2000)

[15] El-Nahhas, F., Awad, T. and Abd-Moatty, N., "Prediction of Ground Heave due to Swelling of Multi Layered Soil Deposits", 8th Int. Colloquium on Structural and Geotech. Eng., Faculty of Engineering, Ain Shams University, (1998). 